\title{
SYNTHESIS AND CHARACTERIZATION OF NEW 2-(2-THIENYL)-5- ARYL-1,3,4-OXADIAZOLES
}

\author{
CARMELLINA DANIELA BĂDICEANU ${ }^{1}$, DIANA CAMELIA NUȚĂ ${ }^{1}{ }^{*}$, ALEXANDRU-VASILE \\ MISSIR $^{1}$, MĂDĂLINA HRUBARU ${ }^{2}$, CARMEN LIMBAN ${ }^{1}$ \\ ${ }^{I}$ Department of Pharmaceutical Chemistry, Faculty of Pharmacy, "Carol Davila” University of Medicine and Pharmacy, 6 \\ Traian Vuia, Bucharest, 020956, Romania \\ 2 “C. D. Nenițescu” Organic Chemistry Center, Romanian Academy, 202B Splaiul Independenței, 060023, Bucharest, \\ Romania
}

*corresponding author: diananuta@yahoo.com

Manuscript received: April 2018

\begin{abstract}
A series of new 1,3,4-oxadiazole derivatives incorporating thiophene moiety were synthesized by the cyclization of $\mathrm{N}-(2$ thenoyl)-N'-aroylhydrazine in the presence of phosphorus oxychloride. The intermediate and final compounds were characterized by infrared (IR), nuclear magnetic resonance $\left({ }^{1} \mathrm{H}-\mathrm{NMR}\right.$ and $\left.{ }^{13} \mathrm{C}-\mathrm{NMR}\right)$ spectroscopy, and by their physicochemical properties.
\end{abstract}

\section{Rezumat}

$\mathrm{Au}$ fost sintetizați o serie de noi derivați ai 1,3,4-oxadiazolului având și un nucleu tiofenic, prin ciclizarea N-(2-tenoil)-N'aroilhidrazinei în prezența oxiclorurii de fosfor. Compușii intermediari și cei finali au fost caracterizați prin spectroscopie în infraroșu (IR) şi rezonanţă magnetică nucleară $\left({ }^{1} \mathrm{H}-\mathrm{RMN}\right.$ şi $\left.{ }^{13} \mathrm{C}-\mathrm{RMN}\right)$, precum şi prin proprietăţile lor fizico-chimice.

Keywords: $1,3,4$-oxadiazole, thiophene, ${ }^{1} \mathrm{H}-\mathrm{NMR},{ }^{13} \mathrm{C}-\mathrm{NMR}$

\section{Introduction}

1,3,4-Oxadiazole heterocyclic core is a versatile lead molecule for designing several potential bioactive agents. 1,3,4-Oxadiazole derivatives are reactive pharmacophores and exhibit a wide range of biological activities including antibacterial $[3,4,7]$, antitubercular [10], antifungal [13, 18], antiviral [8], cytotoxic [15], anticancer $[9,17]$, anti-inflammatory and analgesic $[2,11,22]$ activities.

A variety of therapeutically active agents such as raltegravir (antiretroviral drug), zibotentan (anticancer agent), furamizole (nitrofuran antibacterial agents), tiodazosin and nesapidil (antihypertensive agents) are based on 1,3,4-oxadiazole moiety [23].

The microbiological test of 2-[5-thiol-1,3,4-oxadiazol-2-yl]-9(10H)-acridone on bacteria (Staphylococcus aureus, Streptococcus viridans and Escherichia coli) and fungi (Gibberela spp, Cercospora arachidicola, Physolospora piricola and Fusarium oxysporum) has shown that the compound have a significant biological activity due to the substitution with $1,3,4$ oxadiazole ring which might increase the lipophilic properties of the molecule, and facilitating the crossing through the biological membrane of the microorganism and inhibiting their growth [21].

A series of 1,3,4-oxadiazole derivatives containing substituted phenyl moiety was synthesized and screened for their antimicrobial activity against Escherichia coli, Staphylococcus aureus, Pseudomonas aeruginosa, Cryptococcus neoformans, Candida albicans and Candida glabrata. The antimicrobial screening revealed that compounds having phenyl radical substituted with chlorine in para position and in 3 and 4 positions and also substituted with fluorine in 3 and 4 positions, exhibited good activity [16].

New 3-acetyl-5-(3-chloro-1-benzo[b]thiophen-2-yl)2-substituted phenyl-2,3-dihydro-1,3,4-oxadiazoles and 2-(3-chloro-1-benzo[b]thiophen-2-yl)-5-substituted phenyl-1,3,4-oxadiazoles have been synthesized and screened for their antibacterial activities against Staphylococcus aureus, Bacillus subtilis, Escherichia coli and Pseudomonas aeruginosa and for antifungal activity against Candida albicans and Aspergillus niger. From the first class, compounds with methoxy group in 3 or 4 positions were found to be most potent with better activities than the standard drug, ciprofloxacin, against Staphylococcus aureus and Bacillus subtilis [5].

The antimicrobial activities of the new 1,3,4-oxadiazole derivatives having 6-bromonaphthalene moiety were carried out and some of these compounds showed good activity [14], which was attributed to the presence of the active group attached to phenyl group at position 5 of the oxadiazole ring. The presence of aryl moiety carrying chloro and dichloro group enhanced the activity compared to the 
FARMACIA, 2018, Vol. 66, 3

standard (cyclopiroxolamine) against Tricophyton mentagrophytes, Aspergillus flavus and Aspergillus fumigatus.

A novel series of 2-[3-(4-bromophenyl)propan-3one]-5-(substituted phenyl)-1,3,4-oxadiazoles have been synthesized and were found to have significant anti-inflammatory and analgesic activities, while a few compounds showed appreciable antibacterial activity. Only 2-[3-(4-bromophenyl)propan-3-one]-5(4-fluorophenyl)-1,3,4-oxadiazole had comparable anti-microbial activity with the standard (nitrofurazone) against Staphylococcus aureus with MIC of $12.5 \mathrm{mg} / \mathrm{mL}$, indicating once again the importance of the substitution with fluorine of phenyl ring in the para position [6].

New 5-(1-/2-naphthyloxymethyl)-1,3,4-oxadiazole2(3H)-thione, 2-amino-5-(1-/2-naphthyloxymethyl)1,3,4-oxadiazole, 5-(1-/2-naphthyloxymethyl)-1,3,4oxadiazole-2 $(3 \mathrm{H})$-one derivatives have been synthesized and the antimicrobial properties of the compounds were investigated against Staphylococcus aureus, Escherichia coli and Pseudomonas aeruginosa, Candida albicans, Candida krusei and Candida parapsilosis, the most active being the 1-naphthylderivatives having an amino- or oxo-substitution at 2 position of 1,3,4-oxadiazole ring. All the compounds were active against Staphylococcus aureus, Escherichia coli, Pseudomonas aeruginosa, Candida albicans, and Candida parapsilosis in the $64-256 \mu \mathrm{g} / \mathrm{mL}$ concentration range [20].

Moreover, thiophene derivatives are undoubtedly one of the most important classes of heterocycles, because some molecules containing thiophene scaffold have been reported to exhibit interesting pharmaceutical properties, including antimicrobial [19], anticancer [24] and anti-inflammatory effects [12]. The cytotoxicity of a new 1,3,4-oxadiazole compounds containing 5-phenyl thiophene moiety were compared with the cytotoxicity of the usual standard, 5fluorouracil. Three cell lines were used for the cytotoxic evaluation namely, HepG2, Caco-2 and PANC-1. The compounds showed cytotoxicity against human colorectal carcinoma cell line (Caco-2) with IC50 comparable to that of 5-fluorouracil [1].

Recent challenges in drug research emphasize the design of drugs that combine the pharmacophores. This study aimed the combination of 1,3,4-oxadiazole and thiophene scaffold structure in order to obtain new compounds with increased antimicrobial activity.

\section{Materials and Methods}

All the reagents were commercially obtained (Merck, Sigma-Aldrich or Fluka) and used as received, without further purification.
Melting points were determined by the open capillary method with an Electrothermal 9100 apparatus (Bibby Scientific Ltd, Stone, U.K.) and were uncorrected.

The IR spectra were recorded on a Bruker Vertex 70 FT-IR spectrometer (Bruker Corporation, Billerica, MA, USA). The IR bands were given as w - weak, $\mathrm{m}$ - medium, $\mathrm{s}$ - strong, vs - very strong.

${ }^{1} \mathrm{H}-\mathrm{NMR}$ and ${ }^{13} \mathrm{C}-\mathrm{NMR}$ spectra were recorded (DMSO-d6) on a Gemini 300BB instrument (Varian Medical Systems, Palo Alto, CA, USA), operating at $300 \mathrm{MHz}$ for ${ }^{1} \mathrm{H}$ and $75 \mathrm{MHz}$ for ${ }^{13} \mathrm{C}$. Chemical shift values are given in $\delta$ units (ppm) and the coupling constants are in Hertz.

In the NMR spectra, chemical shifts were recorded in parts per million (ppm) downfield from tetramethylsilane. The splitting patterns of ${ }^{1} \mathrm{H}-\mathrm{NMR}$ were designated as follows: $\mathrm{d}-$ doublet, $\mathrm{t}-$ triplet, $\mathrm{q}-$ quartet, $\mathrm{dd}$ - double doublet, $\mathrm{dt}$ - double triplet and br - broad signal.

The ${ }^{1} \mathrm{H}-\mathrm{NMR}$ data are reported in the following order: chemical shifts, multiplicity, the coupling constants, number of protons and signal/atom attribution.

For the ${ }^{13} \mathrm{C}-\mathrm{NMR}$ data the following order is: chemical shifts and signal/atom attribution $(\mathrm{Cq}-$ quaternary carbon).

Synthesis of $N$-(2-tenoyl)- $N$ '-aroylhydrazines

In a round bottom flask equipped with stirrer was added 0.01 mole of 2-thiophenecarboxylic acid hydrazide, 0.01 mole of substituted aroyl-chloride and $10 \mathrm{~mL}$ of anhydrous pyridine. The reaction mixture was stirred at room temperature for 2 - 3 hours, then poured onto a cold $10 \% \mathrm{HCl}$ solution. A white or light-yellow precipitate was obtained, filtered and washed with distilled water.

Synthesis of 2-(2-thienyl)-5-aryl-1,3,4-oxadiazoles

Research on the 1,3,4-oxadiazole derivatives class has led to the conclusion that one of the most advantageous methods for their preparation is the cyclization of $\mathrm{N}, \mathrm{N}^{\prime}$-diacylhydrazines under the action of various agents (phosphorous oxychloride, thionyl chloride, phosphorus pentoxide).

In order to obtain 1,3,4-oxadiazoles we used the following procedure: mixture of N-(2-thenoyl)-N'aroylhydrazine and phosphorous oxychloride $\left(\mathrm{POCl}_{3}\right)$ in a molar ratio of 1:10, was heated on a water bath under anhydrous conditions for 10 hours, then the mixture was cooled and poured into ice. The obtained precipitate was filtered, washed with distilled water and subsequently, purified by recrystallization from ethanol: water 1:1, using charcoal (compounds 1a, 1d, 1e, 1f, 1g), isopropanol (1b), isobutanol (1c).

\section{Results and Discussion}

The chemical structures of all compounds were characterized by spectral methods, and the spectral data were in full agreement with the proposed structures. For the synthesis of 1,3,4-oxadiazoles 
containing thiophene heterocyclic cores (1a-g), it has been necessary to prepare the appropriate $\mathrm{N}-(2-$ thenoyl)-N'-aroylhydrazines (2) by acylation of the 2-thiophenecarboxylic acid hydrazide (3) with various carboxylic acid chlorides (4).

Among the cyclizing agents, the best results were obtained with phosphorus oxychloride when N-(2-
thenoyl)-N'-aroylhydrazine was treated with this in a ratio of $1: 10 \mathrm{~g} / \mathrm{mL}$, heating the mixture on a water bath under anhydrous conditions, for 10 hours and avoiding colouring the reaction mass.

The general scheme for the synthesis of the novel 2-(2thienyl)-5-aryl-1,3,4-oxadiazoles is shown in Figure 1.<smiles>[R]C(=O)NNC(=O)c1cccs1</smiles><smiles>[R]c1nnc(-c2cccs2)o1</smiles><smiles></smiles><smiles>O=[N+]([O-])c1cccc(I)c1</smiles><smiles>Cc1ccc([N+](=O)[O-])cc1</smiles><smiles>COc1ccccc1C</smiles><smiles>Cc1ccc(OC(F)(F)F)cc1</smiles>

$1 \mathrm{e}$<smiles>CCOc1ccc(OCC)c(C)c1</smiles><smiles>CCOc1cc(C)cc(OCC)c1</smiles>

Figure 1.

The general scheme for the synthesis of 2-(2-thienyl)-5-aryl-1,3,4-oxadiazoles

All oxadiazoles were synthesized with good yields. The new compounds are soluble at room temperature in dimtehylsulphoxide (DMSO), and dimethylformamide (DMF), by heating in acetone, chloroform, benzene, toluene, xylene, methanol, ethanol and isopropanol, and insoluble in cold water.

Cyclization of the precursors to the corresponding oxadiazoles is confirmed by the intensive absorption bands in the $1580-1610 \mathrm{~cm}^{-1}$ region characteristic to the vibration of $v_{\mathrm{C}=\mathrm{N}}$ şi $v_{-\mathrm{N}=\mathrm{O}}$ from oxadiazole ring and in the $715-725 \mathrm{~cm}^{-1}$ region due to the deformation vibrations of the heterocycle.

The proton H-5 appear as a doublet of doublets at $7.46-7.73 \mathrm{ppm}$. The most shielded proton, H-4 (bsulphur position) occurs with a range of $7.10-7.23$ ppm as doublet of doublets.

Protons $\mathrm{H}-12 \div \mathrm{H}-16$ have spectral parameters $(\delta, \mathrm{J})$ in accordance with the nature and position of the substituents and in this case the univocal attributions for the benzene ring protons have emerged from the 2-D correlation experiments as well as increment calculations. Obviously, the absence of chemical shifts for hydrazine protons is the evidence of intra-molecular cyclization.

By cyclization of the oxadiazole ring, the quaternary carbon atom in the thiophene nucleus (C-6) suffers a pronounced shielding at 124.98 - $127.51 \mathrm{ppm}$. The oxadiazole ring presents for quaternary carbons C-6 and C-8 atoms signals at $\delta \in 160.48-163.22$ ppm.

The attributions for the signals of C-11 - C-16 atoms from benzene nucleus have also emerged from the connectivity experiments.

All the synthesis compounds have been characterized by ${ }^{1} \mathrm{H}$ NMR, ${ }^{13} \mathrm{C}$ NMR and IR spectral data.

Spectral data

Spectral data of the compounds were in full agreement with the proposed structures.

2-(2-thienyl)-5-(4-chlorophenyl)-1,3,4-oxadiazoles (1a) $\left(\mathrm{M}_{\mathrm{r}}=262.71 \mathrm{~g} / \mathrm{mol}\right)$ : m.p. $125-127^{\circ} \mathrm{C}$; yield $75.3 \%$.

FT-IR (solid in attenuated total reflectance (ATR), $\left.v \mathrm{~cm}^{-1}\right)$ : 3083w; 3065w; 1689s; 1584s; 1475vs; 1404s; $1086 \mathrm{~s} ; 849 \mathrm{~s} ; 728 \mathrm{~s} ; 695 \mathrm{~s}$.

${ }^{1} \mathrm{H}-\mathrm{NMR}$ (DMSO-d6, $\delta$ ppm, $J \mathrm{~Hz}$ ): 7.96 (d, $J=8.8$ $\mathrm{Hz}, 2 \mathrm{H}, \mathrm{H}-12, \mathrm{H}-16) ; 7.74$ (dd, $J=3.8 \mathrm{~Hz}, J=1.1$ $\mathrm{Hz}, 1 \mathrm{H}, \mathrm{H}-3) ; 7.50$ (dd, $J=5.2 \mathrm{~Hz}, J=1.1 \mathrm{~Hz}, 1 \mathrm{H}$, H-5), 7.42 (d, $J=8.8 \mathrm{~Hz}, 2 \mathrm{H}, \mathrm{H}-13, \mathrm{H}-15) ; 7.11$ (dd, $J=5.2 \mathrm{~Hz}, J=3.8 \mathrm{~Hz}, 1 \mathrm{H}, \mathrm{H}-4)$.

${ }^{13} \mathrm{C}-\mathrm{NMR}$ (DMSO-d6, $\delta$ ppm): 163.22 (C-8); 161.01 (C-6); 138.06 (C-14); 130.46 (C-3); 130.00 (C-5); 129.52 (C-13, C-15); 128.52 (C-12, C-16); 128.32 (C-4); 125.00 (C-2); 122.16 (C-11). 
2-(2-thienyl)-5-(3-nitrophenyl)-1,3,4-oxadiazoles (1b) $\left(\mathrm{M}_{\mathrm{r}}=273.26 \mathrm{~g} / \mathrm{mol}\right)$ : m.p. $141-144^{\circ} \mathrm{C}$; yield $86.4 \%$. FT-IR (solid in ATR, $v \mathrm{~cm}^{-1}$ ): $3117 \mathrm{w} ; 3089 \mathrm{w} ; 1620 \mathrm{w}$; 1586vs; 1489w; 1350m; 1035w; 721m.

${ }^{1} \mathrm{H}-\mathrm{NMR}$ (DMSO-d6, $\left.\delta \mathrm{ppm}, J \mathrm{~Hz}\right): 8.85$ (t, $J=1.8 \mathrm{~Hz}$, $1 \mathrm{H}, \mathrm{H}-12) ; 8.42$ (dt, $J=8.1 \mathrm{~Hz}, J=1.1 \mathrm{~Hz}, 1 \mathrm{H}, \mathrm{H}-14)$; 8.34 (dt, $J=8.1 \mathrm{~Hz}, J=1.1 \mathrm{~Hz}, 1 \mathrm{H}, \mathrm{H}-16), 7.82$ $(\mathrm{dd}, J=3.8 \mathrm{~Hz}, J=1.2 \mathrm{~Hz}, 1 \mathrm{H}, \mathrm{H}-3) ; 7.69(\mathrm{t}, J=$ $8.1 \mathrm{~Hz}, 1 \mathrm{H}, \mathrm{H}-15) ; 7.56(\mathrm{dd}, J=5.1 \mathrm{~Hz}, J=1.2 \mathrm{~Hz}$, $1 \mathrm{H}, \mathrm{H}-5) ; 7.16$ (dd, $J=5.1 \mathrm{~Hz}, J=3.8 \mathrm{~Hz}, 1 \mathrm{H}, \mathrm{H}-4)$.

${ }^{13} \mathrm{C}-\mathrm{NMR}$ (DMSO-d6, $\delta$ ppm): 162.63 (C-8); 161.63 (C-6); 148.69 (C-13); 132.56 (C-16); 131.54 (C-3); 130.57 (C-15); 130.55 (C-5); 128.49 (C-4); 126.23 (C-14); 125.41 (C-2); 124.58 (C-11); 121.87 (C-12). 2-(2-thienyl)-5-(4-nitrophenyl)-1,3,4-oxadiazoles (1c) $\left(\mathrm{M}_{\mathrm{r}}=273.26 \mathrm{~g} / \mathrm{mol}\right)$ : m.p. $222-225^{\circ} \mathrm{C}$; yield $72.8 \%$. FT-IR (solid in ATR, $v \mathrm{~cm}^{-1}$ ): 3152w; 3091w; 1609s; 1579s; 1513vs; 1480s; 1336vs; 1033m; 720s; 700s. ${ }^{1} \mathrm{H}-\mathrm{NMR}$ (DMSO-d6, $\delta \mathrm{ppm}, J \mathrm{~Hz}$ ): 8.37 (d, $J=9.0$ $\mathrm{Hz}, 2 \mathrm{H}, \mathrm{H}-13, \mathrm{H}-15)$; 8.25 (d, $J=9.0 \mathrm{~Hz}, 2 \mathrm{H}, \mathrm{H}-12$, $\mathrm{H}-16) ; 7.96$ (dd, $J=3.9 \mathrm{~Hz}, J=1.1 \mathrm{~Hz}, 1 \mathrm{H}, \mathrm{H}-3)$; $7.73(\mathrm{dd}, J=5.0 \mathrm{~Hz}, J=1.1 \mathrm{~Hz}, 1 \mathrm{H}, \mathrm{H}-5) ; 7.23$ (dd, $J=5.0 \mathrm{~Hz}, J=3.9 \mathrm{~Hz}, 1 \mathrm{H}, \mathrm{H}-4)$.

${ }^{13} \mathrm{C}-\mathrm{NMR}$ (DMSO-d6, $\delta \mathrm{ppm}$ ): 162.74 (C-8); 162.04 (C-6); 150.29 (C-14); 133.91 (C-3); 133.24 (C-5); 129.37 (C-4); 128.53 (C-12, C-16); 124.85 (C-13, C-15); 127.51 (C-2); 121.75 (C-11).

2-(2-thienyl)-5-(2-ethoxyphenyl)-1,3,4-oxadiazoles (1d) $\left(\mathrm{M}_{\mathrm{r}}=272.32 \mathrm{~g} / \mathrm{mol}\right)$ : m.p. $75-77^{\circ} \mathrm{C}$; yield $79.8 \%$.

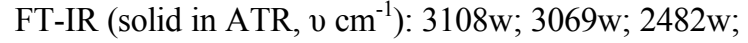
2932w; 1601s, 1583s; 1508s; 1465s; 1270vs; 1035i; 741s; 698s.

${ }^{1} \mathrm{H}-\mathrm{NMR}$ (DMSO-d6, $\delta$ ppm, $J \mathrm{~Hz}$ ): 7.96 (dd, $J=7.7$ $\mathrm{Hz}, J=2.9 \mathrm{~Hz}, 1 \mathrm{H}, \mathrm{H}-16), 7.72$ (dd, $J=3.5 \mathrm{~Hz}, J=1.3$ $\mathrm{Hz}, 1 \mathrm{H}, \mathrm{H}-3) ; 7.46$ (dd, $J=4.9 \mathrm{~Hz}, J=1.3 \mathrm{~Hz}, 1 \mathrm{H}$, H-5); 7.40 (td, $J=8.8 \mathrm{~Hz}, J=1.7 \mathrm{~Hz}, 1 \mathrm{H}, \mathrm{H}-14)$; $7.10(\mathrm{dd}, J=4.9 \mathrm{~Hz}, J=3.5 \mathrm{~Hz}, 1 \mathrm{H}, \mathrm{H}-4) ; 6.95(\mathrm{br}$ d, $J=8.5 \mathrm{~Hz}, 1 \mathrm{H}, \mathrm{H}-13$ ); ); 6.98 (br t, $J=8.5 \mathrm{~Hz}$, $1 \mathrm{H}, \mathrm{H}-15) ; 4.10$ (q, $J=7.2 \mathrm{~Hz}, 2 \mathrm{H},-\mathrm{O}-\mathrm{CH}_{2}-\mathrm{CH}_{3}$ ); $1.45\left(\mathrm{t}, J=7.2 \mathrm{~Hz}, 3 \mathrm{H},-\mathrm{O}-\mathrm{CH}_{2}-\mathrm{CH}_{3}\right)$.

${ }^{13} \mathrm{C}-\mathrm{NMR}$ (DMSO-d6, $\delta$ ppm): 163.17 (C-8); 160.79 (C-6); 157.21 (C-12); 133.12 (C-16); 130.55 (C-3); 129.85 (C-14); 129.44 (C-5); 128.19 (C-4); 125.67 (C-2); 112.98 (C-13); 120.70 (C-15); 110.05 (C-11); $64.56\left(-\mathrm{O}-\mathrm{CH}_{2}-\mathrm{CH}_{3}\right) ; 14.94\left(-\mathrm{O}-\mathrm{CH}_{2}-\mathrm{CH}_{3}\right)$.

2-(2-thienyl)-5-(4-trifluoromethoxyphenyl)-1,3,4-oxadiazoles $(1 \mathrm{e})\left(\mathrm{M}_{\mathrm{r}}=312.26 \mathrm{~g} / \mathrm{mol}\right)$ : m.p. $103-106^{\circ} \mathrm{C}$; yield $64.2 \%$.

FT-IR (solid in ATR, $v \mathrm{~cm}^{-1}$ ): 3099w; 1588m; 1493m; 1262s; 1208vs; 1168vs; 758w; 749m.

${ }^{1} \mathrm{H}-\mathrm{NMR}$ (DMSO-d6, $\delta$ ppm, $J \mathrm{~Hz}$ ): 8.09 (d, $J=8.0$ $\mathrm{Hz}, 2 \mathrm{H}, \mathrm{H}-12, \mathrm{H}-16) ; 7.76$ (dd, $J=3.8 \mathrm{~Hz}, J=1.1$ $\mathrm{Hz}, 1 \mathrm{H}, \mathrm{H}-3$ ); 7.51 (dd, $J=5.0 \mathrm{~Hz}, J=1.1 \mathrm{~Hz}, 1 \mathrm{H}$, H-5), 7.26 (br d, $J=8.0 \mathrm{~Hz}, 2 \mathrm{H}, \mathrm{H}-13, \mathrm{H}-15$ ); 7.13 (dd, $J=5.0 \mathrm{~Hz}, J=3.8 \mathrm{~Hz}, 1 \mathrm{H}, \mathrm{H}-4)$.

${ }^{13} \mathrm{C}-\mathrm{NMR}$ (DMSO-d6, $\delta$ ppm): 162.96 (C-8); 161.16 (C-6); 151.63 (q, $J=1.9 \mathrm{~Hz}, \mathrm{C}-14) ; 130.53$ (C-3); 130.07 (C-5); 128.79 (C-12, C-16); 128.34 (C-4);
124.98 (C-2); 122.27 (C-11); 122,10 (q, $J=1.1 \mathrm{~Hz}$, $\mathrm{C}-13, \mathrm{C}-15) ; 120.38$ (q, $\left.J=258.5 \mathrm{~Hz},-\mathrm{OCF}_{3}\right)$.

2-(2-thienyl)-5-(2,5-diethoxyphenyl)-1,3,4-oxadiazoles (1f) $\left(\mathrm{M}_{\mathrm{r}}=316.37 \mathrm{~g} / \mathrm{mol}\right):$ m.p. $85-89^{\circ} \mathrm{C}$; yield $78.5 \%$.

FT-IR (solid in ATR, $v$ cm-1): 3116w; 2474w; $2931 \mathrm{w} ; 2889 \mathrm{w} ; 1585 \mathrm{~m} ; 1532 \mathrm{~m} ; 1489 \mathrm{~s} ; 1470 \mathrm{~s}$; $1444 \mathrm{~m} ; 1394 \mathrm{~m} ; 1224 \mathrm{vs} ; 1041 \mathrm{vs} ; 725 \mathrm{vs}$.

${ }^{1} \mathrm{H}-\mathrm{NMR}$ (DMSO-d6, $\delta$ ppm, $J \mathrm{~Hz}$ ): 7.73 (dd, $J=$ $3.9 \mathrm{~Hz}, J=1.1 \mathrm{~Hz}, 1 \mathrm{H}, \mathrm{H}-3) ; 7.50(\mathrm{~d}, J=2.8 \mathrm{~Hz}$, $1 \mathrm{H}, \mathrm{H}-16) ; 7.47$ (dd, $J=5.1 \mathrm{~Hz}, J=1.1 \mathrm{~Hz}, 1 \mathrm{H}, \mathrm{H}-5)$; $7.10(\mathrm{dd}, J=5.1 \mathrm{~Hz}, J=3.9 \mathrm{~Hz}, 1 \mathrm{H}, \mathrm{H}-4) ; 6.96$ (dd, $J=9.0 \mathrm{~Hz}, J=2.8 \mathrm{~Hz}, 1 \mathrm{H}, \mathrm{H}-14) ; 6.90$ (d, $J=9.0$ $\mathrm{Hz}, 1 \mathrm{H}, \mathrm{H}-13$ ); 4.05 (q, $J=7.2 \mathrm{~Hz}, 2 \mathrm{H},-\mathrm{O}-\mathrm{CH}_{2}-\mathrm{CH}_{3}$ ); 1.39 (t, $J=7.2 \mathrm{~Hz}, 3 \mathrm{H},-\mathrm{O}-\mathrm{CH}_{2}-\mathrm{CH}_{3}$ ).

${ }^{13} \mathrm{C}-\mathrm{NMR}$ (DMSO-d6, $\left.\delta \mathrm{ppm}\right): 163.11$ (C-8); 160.89 (C-6); 152.83 (C-12); 151.48 (C-15); 129.92 (C-3); 129.52 (C-5); 128.22 (C-4); 125.65 (C-2); 120.16 (C-16); 115.21 (C-14); 114.97 (C-13); 113.54 (C$11) ; 65.48\left(-\mathrm{O}-\mathrm{CH}_{2}-\mathrm{CH}_{3}\right) ; 15.14\left(-\mathrm{O}-\mathrm{CH}_{2}-\mathrm{CH}_{3}\right)$.

2-(2-thienyl)-5-(3,5-diethoxyphenyl)-1,3,4-oxadiazoles (1g) $\left(\mathrm{M}_{\mathrm{r}}=316.37 \mathrm{~g} / \mathrm{mol}\right):$ m.p. $93-95^{\circ} \mathrm{C}$; yield $75.1 \%$. FT-IR (solid in ATR, v cm${ }^{-1}$ ): 3097w; 3077w; 2977w; 2933w; 2815w; 1599s; 1550s; 1468m; 1392m; 1338m; $1173 \mathrm{vs} ; 1093 \mathrm{~m} ; 1055 \mathrm{~m} ; 727 \mathrm{~s}$.

${ }^{1} \mathrm{H}-\mathrm{NMR}$ (DMSO-d6, $\delta$ ppm, $J \mathrm{~Hz}$ ): 7.75 (dd, $J=3.8$ $\mathrm{Hz}, J=1.1 \mathrm{~Hz}, 1 \mathrm{H}, \mathrm{H}-3) ; 7.49$ (dd, $J=3.8 \mathrm{~Hz}, J=1.1$ $\mathrm{Hz}, 1 \mathrm{H}, \mathrm{H}-5) ; 7.15$ (d, $J=2.2 \mathrm{~Hz}, 2 \mathrm{H}, \mathrm{H}-12, \mathrm{H}-16$ ); $7.12(\mathrm{dd}, J=4.9 \mathrm{~Hz}, J=3.8 \mathrm{~Hz}, 1 \mathrm{H}, \mathrm{H}-4) ; 6.53(\mathrm{t}$, $J=2.2 \mathrm{~Hz}, 1 \mathrm{H}, \mathrm{H}-14) ; 4.02$ (q, $J=7.2 \mathrm{~Hz}, 2 \mathrm{H}$, $-\mathrm{O}-\mathrm{CH}_{2}-\mathrm{CH}_{3}$ ); 1.37 (t, $J=7.2 \mathrm{~Hz}, 3 \mathrm{H},-\mathrm{O}-\mathrm{CH}_{2}-\mathrm{CH}_{3}$ ). ${ }^{13} \mathrm{C}-\mathrm{NMR}$ (DMSO-d6, $\delta$ ppm): 161.88 (C-8); 160.48 (C-6); 160.47 (C-13, C-15); 130.23 (C-3); 129.83 (C-5); 128.22 (C-4); 125.22 (C-2); 125.02 (C-11); 105.22 (C-12, C-16); 105.03 (C-14); 63.48 (-O$\left.\mathrm{CH}_{2}-\mathrm{CH}_{3}\right) ; 14.87\left(-\mathrm{O}-\mathrm{CH}_{2}-\mathrm{CH}_{3}\right)$.

\section{Conclusions}

In the process to discover new candidates having improved antimicrobial activity, a series of seven new 1,3,4-oxadiazole analogues containing thiophene moiety, and having various substituents on the phenyl attached to 1,3,4-oxadiazole ring, were synthesized, and well characterized by IR, ${ }^{1} \mathrm{H}-\mathrm{NMR}$ and ${ }^{13} \mathrm{C}-\mathrm{NMR}$ spectrometry.

Thus, the mixed compounds containing both 1,3,4oxadiazole and thiophene moieties can serve as interesting lead molecules for further biological evaluations.

\section{References}

1. Adimule V, Medapa S, Jagadeesha AH, Kumar LS, Prakash Rao K, Synthesis, characterization and cytotoxic evaluation of novel derivatives of 1,3,4oxadiazole containing 5-phenyl thiophene moiety. IOSR J Pharm Biol Sci., 2014; 9(5): 42-48. 
2. Akhter M, Husain A, Azad B, Ajmal M, Aroylpropionic acid based 2,5-disubstituted-1,3,4-oxadiazoles: synthesis and their anti-inflammatory and analgesic activities. Eur J Med Chem., 2009; 44(6): 2372-2378.

3. Bădiceanu CD, Nuță DC, Missir AV, Hrubaru M, Delcaru C, Dițu LM, Chifiriuc MC, Limban C, New derivatives of 2-thiophene carboxylic acid: synthesis, structure and antimicrobial studies Farmacia, 2018; 66(2): 237-242.

4. Bărbuceanu SF, Băncescu G, Crețu OD, Drăghici C, Băncescu A, Radu-Popescu M, New heterocyclic compounds from 1,3,4-thiadiazole, 1,3,4-oxadiazole and 1,2,4-triazole class with potential antibacterial activity. Rev Chim (Bucureşti), 2010; 61(2): 140-145.

5. Chawla R, Arora A, Parameswaran MK, Sharma PC, Michael S, Ravi TK, Synthesis of novel 1,3,4oxadiazole derivatives as potential antimicrobial agents. Acta Pol Pharm., 2010; 67(3): 247-253.

6. Husain A, Ajmal M, Synthesis of novel 1,3,4oxadiazole derivatives and their biological properties. Acta Pharm., 2009; 59: 223-233.

7. Jafari E, Mohammadi T, Jahanian-Najafabadi A, Hassanzadeh F, Synthesis and antimicrobial evaluation of some 2,5 disubstituted 1,3,4-oxadiazole derivatives. Res Pharm Sci., 2017; 12(4): 330-336.

8. Küçükgüzel SG, Oruç EE, Rollas S, Sahin F, Ozbek A, Synthesis, characterisation and biological activity of novel 4-thiazolidinones, 1,3,4-oxadiazoles and some related compounds. Eur J Med Chem., 2002; 37(3): 197-206.

9. Kumar D, Sundaree S, Johnson EO, Shah K, An efficient synthesis and biological study of novel indolyl-1,3,4-oxadiazoles as potent anticancer agents. Bioorg Med Chem Lett., 2009; 19: 4492-4494.

10. Kumar GVS, Rajendraprasad Y, Mallikarjuna BP, Chandrashekar SM, Kistayya C, Synthesis of some novel 2-substituted-5-[isopropylthiazole]clubbed 1,2,4-triazole and 1,3,4-oxadiazoles as potential antimicrobial and anti-tubercular agents. Eur J Med Chem., 2010; 45: 2063-2074.

11. Kumar H, Javed SA, Khan SA, Amir M, 1,3,4oxadiazole/thiadiazole and 1,2,4-triazole derivatives of biphenyl-4-yloxy acetic acid: synthesis and preliminary evaluation of biological properties. Eur J Med Chem., 2008; 43(12): 2688-2698.

12. Kumar PR, Raju S, Goud PS, Sailaja M, Sarma MR, Reddy GO, Kumar MP, Krishna Reddy VVRM, Suresh T, Hedge P, Synthesis and biological evaluation of thiophene[3,2-b]pyrrole derivatives as potential anti-inflammatory agents. Bioorg Med Chem., 2004; 12: 1221-1230.

13. Maslat AO, Abussaud M, Tashtoush H, Al-Talib M, Synthesis, antibacterial, antifungal and genotoxic activity of bis-1,3,4-oxadiazole derivatives. Pol $J$ Pharmacol., 2002; 54(1): 55-59.

14. Mayekar AN, Yathirajan HS, Narayana B, Sarojini BK, Suchetha Kumari N, Synthesis and antimicrobial studies on new substituted 1,3,4-oxadiazole derivatives bearing 6-bromonaphthalene moiety. Int $J$ Chem., 2010; 2(1): 38-54.

15. Padmavathi V, Sudhakar Reddy G Padmaja A., Kondaiah P, Ali-Shazia P, Synthesis, antimicrobial and cytotoxic activities of 1,3,4-oxadiazoles, 1,3,4thiadiazoles ann 1,2,4-triazoles. Eur J Med Chem., 2009; 44: 2106-2112.

16. Pagare AH, Kankate RS, Shaikh AR, Synthesis and antimicrobial evaluation of newer 1,3,4-oxadiazole derivatives containing R-phenyl moiety under conventional conditions. Res J Chem Environ Sci., 2016; 4(2): 45-50.

17. Polkam N, Kummari B, Rayam P, Brahma U, Naidu VGM, Sridhar Balasubramanian S, Anireddy JS, Synthesis of 2,5-disubstituted-1,3,4-oxadiazole derivatives and their evaluation as anticancer and antimycobacterial agents. Chem Select., 2017; 2(20): 5492-5496.

18. Prakash O, Kumar M, Kumar R, Sharma C, Aneja KR, Hypervalent iodine(III) mediated synthesis of novel unsymmetrical 2,5-disubstituted 1,3,4-oxadiazoles as antibacterial and antifungal agents. Eur J Med Chem., 2010; 45(9): 4252-4257.

19. Queiroz MRP, Ferreira ICFR, Gaetano YD, Kirsch G, Calhelha RC, Estevinho LM, Synthesis and antimicrobial activity studies of orthochlorodiarylamines and heteroaromatic tetracyclic systems in the benzo [b]thiophene series. Bioorg Med Chem., 2006; 14: 6827-6831.

20. Sahin G, Palaska E, Ekizoğlu M, Ozalp M, Synthesis and antimicrobial activity of some 1,3,4-oxadiazole derivatives. Farmaco., 2002; 57(7): 539-542.

21. Salimon J, Salih N, Yousif E, Hameed A, Kreem A, Synthesis and pharmacological evaluation of $9(10 \mathrm{H})-$ acridone bearing 1,3,4-oxadiazole derivatives as antimicrobial agents. Arab J Chem., 2010; 3: 205-210.

22. Singh AK, Lohani M, Parthsarthy R, Synthesis, characterization and anti-inflammatory activity of some 1,3,4-oxadiazole derivatives. Iranian J Pharm Res., 2013; 12: 319-323.

23. Singh R, Chouhan A, Various approaches for synthesis of 1,3,4-oxadiazole derivatives and their pharmacological activity. World J Pharm Sci., 2014; 3(10): 1474-1505.

24. Thomson P, Naylor MA, Everett SA, Stratford MRL, Lewis G, Hill S, Patel KB, Wardman P, Davis PD, Synthesis and biological properties of bioreductively targeted nitrothienyl prodrugs of combretastatin A-4. Mol Cancer Therapeut., 2006; 5: 2886-2894. 